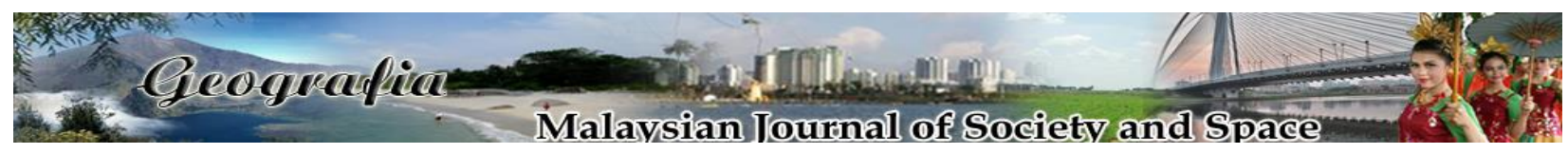

\title{
Kajian komposisi dan pengasingan sisa pepejal di kawasan perumahan
}

\author{
Mohammad Tahir Mapa ${ }^{1}$, Lokman Mohd Haris ${ }^{2}$, Fionna Geogre ${ }^{1}$, Molia Sebi Dinggai ${ }^{1}$, \\ Adi Japar ${ }^{1}$, Aliakbar Gulasan ${ }^{1}$ \\ ${ }^{1}$ Program Geografi, Fakulti Kemanusiaan, Seni dan Warisan, Universiti Malaysia Sabah \\ ${ }^{2}$ Pejabat Pengarah Tanah Dan Galian, Ipoh, Perak \\ Correspondence: Mohammad Tahir Mapa (email: herma@ums.edu.my)
}

Received: 15 February 2019; Accepted: 4 April 2019; Published: 14 May 2019

\begin{abstract}
Abstrak
Taraf ekonomi yang semakin meningkat dan peningkatan jumlah penduduk menjadi antara faktor pendorong kepada peningkatan jumlah sisa pepejal di sesuatu kawasan. Lambakan ini secara umumnya akan memberi ke atas alam sekitar, terutamanya di kawasan bandar dan petempatan penduduk. Situasi semasa menunjukkan isu penjanaan dan komposisi sisa pepejal semakin membimbangkan, terutamanya di negara-negara membangun seperti Malaysia. Kajian ini bertujuan mengenal pasti komposisi sisa di kawasan perumahan dengan menggunakan pendekatan yang digunakan dalam Akta 672. Kaedah survei yang digunakan dalam kajian ini melibatkan sebanyak 100 orang responden kajian yang dipilih secara rawak daripada dua kawasan perumahan iaitu Taman Megah Jaya dan Kampong Rawa-Rawa. Kajian komposisi dilakukan melalui pengasingan dan penimbangan secara terus. Hasil kajian mendapati, wujud perbezaan jumlah sisa baki dan sisa kitar semula di kedua-dua kawasan. Walaupun perbezaan yang didapati tidak ketara, responden di kawasan perumahan kampung lebih cenderung untuk melakukan pengasingan sisa boleh kitar berbanding mereka yang tinggal di kawasan perumahan taman. Faktor kewangan diandaikan sebagai pendorong utama untuk mereka melakukan pengasingan dengan sebahagian besar daripada mereka menjual sisa kitar semula yang dikumpul. Oleh itu, aktiviti ini perlu diberi perhatian serius oleh semua pihak dengan mengadakan usaha sama agar sisa kitar semula dapat diguna semula oleh pihak industri.
\end{abstract}

Kata kunci: Akta 672, kediaman, komposisi sisa, pengasingan sisa, sisa kitar semula, sisa pepejal 


\title{
Solid waste composition and segregation study in residential area
}

\begin{abstract}
Improving economic growth and rising population are among the driving factors for the increase in the amount of solid waste. The raise in solid waste generally affects the environment especially in urban and residential areas. The current situation shows the issue of solid waste generation and composition is getting more serious especially, in developing countries like Malaysia. The purpose of this study is to identify the waste composition in the housing area by using the method suggested in the Solid Waste Management and Public Cleansing Act (Act 672). Survey method was used in this study with 100 respondents randomly selected from two housing area namely Taman Megah Jaya and Kampong Rawa-Rawa. The waste composition study was conducted on all respondents by direct separation and weighing. The findings show that there is a difference in the amount of residual waste and recyclable waste in both areas. Although the difference is not significant, respondents in the village housing area are more likely to separate their recyclable waste than respondents living in terraced housing areas. Financial factors are assumed to be the main drivers for respondents to carry out separation with most of them selling the collected waste. Therefore, separation activities need to be taken seriously by all parties by establishing joint ventures in collecting recyclable wastes so that it can be reused by the industry.
\end{abstract}

Keywords: Act 672, residential, waste compositions, waste segregation, recyclable, solid waste

\section{Pengenalan}

Taraf ekonomi yang semakin meningkat ditambah dengan peningkatan jumlah penduduk telah mendorong kepada peningkatan jumlah sisa pepejal di sesuatu kawasan (National Solid Waste Management Department, 2013). Lambakan sisa pepejal daripada aktiviti manusia secara umumnya akan memberi kesan ke atas alam sekitar terutamanya di kawasan perbandaran dan petempatan penduduk. Situasi semasa menunjukkan isu penjanaan dan komposisi sisa pepejal semakin membimbangkan dengan sisa pepejal semakin meningkat terutamanya di kebanyakan negeri di Semenanjung Malaysia. Kira-kira 25,000 tan sehari sisa pepejal telah dijana pada tahun 2012 di Semenanjung Malaysia sahaja. Dari jumlah tersebut, hanya lima peratus sahaja yang telah dikitar semula (Jabatan Pengurusan Sisa Pepejal Negara, 2012). Hal ini disebabkan oleh sikap masyarakat yang belum peka terhadap kepentingan pengasingan sisa di punca. Pada masa ini, 95 peratus sisa pepejal dilupuskan melalui kaedah tapak pelupusan. Pada tahun 2016 terdapat 158 tapak pelupusan yang beroperasi di seluruh negara dan pada 2015 terdapat 14 tapak yang di kategorikan sebagai tapak pelupusan sanitari (Kementerian Perumahan dan Kerajaan Tempatan, 2017).

Sebagai sebuah negara sedang membangun, Malaysia tidak terkecuali daripada menghadapi masalah berkaitan dengan pembuangan sisa pepejal sama seperti di negara sedang membangun lain. Penjanaan sisa pepejal dipengaruhi oleh beberapa faktor seperti kedudukan geografi, taraf hidup penduduk dan iklim. Tidak dinafikan bahawa masalah pertambahan sisa pepejal berpunca daripada sikap masyarakat itu sendiri yang secara langsung menyebabkan lambakan sisa di tapak pelupusan sedia ada. Kelemahan dalam pengurusan sisa pepejal semakin membimbangkan 
apabila kurangnya kemudahan infrastruktur, peruntukan modal yang sedikit dan teknologi yang rendah. Keadaan ini menjadi semakin serius apabila jumlah sisa semakin bertambah dengan peningkatan penduduk. Masalah ini juga menjadi semakin kompleks apabila komposisi sisa semakin pelbagai.

Malaysia telah memulakan dasar mewajibkan pengasingan sisa pepejal isi rumah (dipunca) secara berperingkat bermula 1 September 2015 di beberapa negeri terpilih di Semenanjung Malaysia sehingga 1 Jun 2016. Negeri-negeri tersebut ialah Wilayah Persekutuan Kuala Lumpur, Putrajaya, Pahang, Johor, Melaka, Negeri Sembilan, Perlis dan Kedah. Sehingga ke tarikh tersebut tiada sebarang denda dikenakan sekiranya gagal mengasingkan sisa pepejal. Selepas tarikh tersebut, kompaun akan dikenakan sebanyak RM50 bagi kesalahan pertama dan jumlah tersebut akan meningkat sejajar dengan kesalahan yang dilakukan. Pelaksanaan pengasingan dipunca adalah selaras dengan peraturan yang terkandung dalam Akta Pengurusan Sisa Pepejal dan Pembersihan Awam (Akta 672). Proses pengasingan sisa pepejal isi rumah dilakukan mengikut kategori komposisi sisa seperti sisa kitar semula dan sisa baki. Sisa-sisa yang diasingkan akan dikutip setiap minggu mengikut jadual yang ditetapkan (Jabatan Pengurusan Sisa Pepejal Negara 2018)

Namun pada masa ini, Sabah masih tidak mempunyai satu peraturan khusus mengenai pengasingan sisa dipunca dan ini menyebabkan negeri ini berdepan dengan longgokan sisa kitar semula. Selain itu situasi ini juga menjadi masalah dalam pengurusan sisa pepejal ditambah lagi dengan sikap masyarakat. Ketiadaan peraturan, garis panduan atau undang-undang telah menjadikan pengurusan sisa di Sabah masih kekal dengan corak pengurusan tradisi. Oleh itu, kajian mengenai komposisi sisa perlu dilakukan untuk memastikan kaedah pengurusan yang sesuai bagi sesuatu kawasan. Kajian ini dijalankan untuk mengenal pasti komposisi sisa pepejal dan menilai amalan pengasingan sisa di kawasan perumahan dalam kawasan pentadbiran Majlis Perbandaran Tawau.

\section{Kajian literatur}

\section{Pengurusan sisa dan penglibatan komuniti}

Menurut Jabatan Pengurusan Sisa Pepejal dan Pembersihan Awam sisa pepejal menjelaskan ditafsirkan sebagai (i) apa-apa bahan sekerap atau benda lebihan lain yang tidak dikehendaki atau keluaran yang ditolak yang timbul daripada penggunaan apa-apa proses; (ii) apa-apa benda yang dikehendaki dilupuskan kerana sudah pecah, lusuh, tercemar atau selainnya rosak atau (iii) apa-apa bahan lain yang mengikut akta ini atau mana-mana undang-undang bertulis lain dikehendaki oleh pihak berkuasa supaya dilupuskan tetapi tidaklah termasuk bahagian terjadual sebagaimana yang diperihalkan di bawah Akta Kualiti Alam Sekeliling 1974 (Akta 172) (National Solid Waste Management Department, 2013). Pengurusan sisa pepejal merangkumi sebarang hirarki, perancangan, kaedah, alternatif yang berkaitan dengan pengurusan, pentadbiran dan juga melupus sisa pepejal (Agamuthu et al., 2001). Di Malaysia, pengurusan sisa pepejal boleh dibahagikan kepada beberapa kaedah seperti kitar semula, pengkomposan, pelupusan di tapak, pembakaran dan pembuangan secara haram (Ta Wee, 2004). Pengurusan sisa pepejal dalam sesebuah komuniti dan pengasingan sisa pepejal amat penting untuk dilaksanakan.

Pertambahan penduduk dan peningkatan taraf sosioekonomi serta perubahan gaya hidup

yang semakin moden telah meningkatkan bahan buangan dari aktiviti domestik, perniagaan dan 
kilang (Mapa et al., 2015). Selain menjadi beban kepada pihak perbandaran, pertambahan sisa pepejal juga menjadi penyebab kepada pencemaran alam sekitar seperti air bawah tanah dan pencemaran laut (UNEP, 2001). Penjanaan sisa pepejal berbeza mengikut kawasan dan tahap kemajuan sesuatu kawasan. Kajian pada tahun 2013 menunjukkan penjanaan sisa isirumah ialah 18,000 tan metrik di Semenanjung Malaysia. Anggaran janaan perkapita dalam beberapa kajian adalah berbeza-beza misalnya 0.5 hingga $0.8 \mathrm{~kg}$ sehari (Agamuthu et al., 2009), 0.8 $\mathrm{kg} / \mathrm{kapita} / \mathrm{hari}$ (National Solid Waste Management Department, 2013). Data terkini dari sumber Kementerian Perumahan dan Kerajaan Tempatan, jumlah sisa pepejal adalah 36,243.88 kg sehari dan anggaran anggaran kadar janaan perkapita (kg/kap/hari) ialah 0.76 (Kementerian Perumahan dan Kerajaan Tempatan, 2018).

Oleh itu, komuniti perlu memainkan peranan yang penting dalam memastikan sisa buangan diasingkan supaya konsep 3R dapat dilaksanakan dengan jayanya. Penyertaan orang ramai dalam mengurus sisa pepejal adalah satu kaedah terpenting ke arah pengurusan sisa mampan di sesebuah kawasan. Penglibatan komuniti merupakan satu pendekatan yang bertujuan untuk memperkasa dan memberi peluang kepada komuniti terlibat secara langsung dan bertanggungjawab dalam mengurus perkhidmatan pengurusan sisa pepejal di kawasan masingmasing. Dalam konteks pengurusan sisa pepejal, penglibatan komuniti bermaksud bahawa komuniti terlibat secara langsung dalam aktiviti pemisahan, penyimpanan, pemungutan dan pemulihan sumber sisa pepejal.

Pihak berkuasa tempatan masih menghadapi masalah dalam mengurus sisa pepejal ekoran pertambahan jumlah sisa yang semakin meningkat saban tahun. Ini terkait dengan kurangnya kesedaran dalam kalangan penduduk untuk mengurus sisa pepejal dengan lebih cekap (Alias et al., 2014). Pendedahan awal terhadap pengurusan sisa pepejal sangat penting agar penduduk memahami dan sedar bahawa pengurusan sisa pepejal yang baik dapat membantu menyelamatkan alam sekitar. Justeru itu, komuniti perlulah dilengkapkan dengan pengetahuan dan kemahiran dalam pengurusan sisa pepejal serta mempunyai sikap yang positif dalam amalan tersebut.

Kajian komposisi secara umumnya menggambarkan tentang komponen-komponen yang terdapat sisa pepejal dan ciri-cirinya. Data komposisi sisa pepejal penting sebagai rujukan kepada pihak berkuasa dalam menentukan sistem pengurusan yang sesuai, kaedah pengolahan sisa dan perancangan pengurusan masa depan di sesuatu kawasan. Ketidaktepatan data mengenai jumlah serta komposisi sisa boleh menjadi penyebab yang menyumbang kepada kegagalan sesuatu program pengurusan sisa pepejal seperti program kitar semula.

Kajian di Jakarta menunjukkan sebahagian besar hasil buangan adalah sisa pepejal organik. Jumlah sampah organik dikaitkan dengan taraf sosioekonomi atau pendapatan masyarakat. Bagi masyarakat yang berpendapatan tinggi, komposisi sisa organik yang dihasilkan adalah lebih tinggi berbanding dengan masayarak berpendatan rendah. Selain dari itu komposisi sisa boleh kitar menunjukan jumlah yang lebih tinggi dalam masayarkat di kawasan kajian(Fatikhah et al., 2010). Kajian komposisi sisa di Malaysia juga mendapati sisa organik merupakan kandungan yang tertinggi begitu juga komponen sisa boleh kitar didapati dalam peratusan yang tinggi (Kassim, 2006).

Di Malaysia, beberapa kajian penjanaan sisa bagi setiap individu telah dijalankan oleh beberapa pengkaji. Kajian di Johor menganggarkan setiap orang menghasilkan 0.5kg hingga $0.8 \mathrm{~kg}$ sisa dalam sehari(Ta Wee, 2004). Namun, kajian oleh Kassim (2006) mendapati secara umumnya, penjanaan sisa pepejal adalah sebanyak $0.40 \mathrm{~kg} / \mathrm{hari} /$ orang iaitu sedikit kurang berbanding kajian-kajian sebelumnya. Dianggarkan penjanaan sisa pepejal di Kota Kinabalu, 
Sabah adalah sebanyak 238 tan/hari atau purata penjanaan $0.68 \mathrm{~kg}$ perkapita sehari (SUDP, 2000). Kadar penjanaan pada tahun tersebut adalah masih rendah daripada kadar penjanaan bagi seluruh negara iaitu $0.76 \mathrm{~kg}$ perkapita sehari (Kementerian Perumahan dan Kerajaan Tempatan, 2018). Satu cabaran paling utama dalam amalan pengaasingan sisa dan kitar semula ialah tindak tanduk masyarakat untuk menjadikan pengasingan dan kitar semula sebagai satu tabiat (Moh \& Abd Manaf, 2017).

\section{Metod dan kawasan kajian}

Kajian ini menggunakan kaedah survei yang menggunakan borang soal selidik sebagai instrumen utama. Borang soal selidik mengandungi soalan berkaitan dengan pemboleh ubah yang telah ditentukan dalam kajian ini. Bagi kajian komposisi, proses menimbang dan membahagikan sisa kepada kategori sisa baki dan sisa kitar semula dijalankan ke atas isi rumah yang dipilih (100 sampel) iaitu 50 sampel bagi setiap kawasan perumahan. Pemilihan sampel adalah secara rawak di kedua-dua kawasan perumahan tersebut. Oleh kerana kajian komposisi sisa adalah sesuatu yang rumit iaitu memerlukan masa yang agak lama untuk proses pengasingan sisa kepada jenisjenis yang telah ditentukan, jumlah yang dipilih adalah memadai untuk tujuan kajian ini dijalankan. Sisa baki adalah terdiri daripada sisa makanan, sisa dapur, bahan-bahan kotor dan lampin pakai buang. Manakala, bagi sisa kitar semula pula terdiri daripada kertas, plastik, sisa kebun, kaca/ seramik, tin aluminium/ besi/ logam, bahan fabrik/ kasut/ getah dan sisa berbahaya. Alat penimbang yang digunakan terdiri daripada tiga jenis iaitu penimbang berkeupayaan $10 \mathrm{~kg}$, $5 \mathrm{~kg}$ dan $2 \mathrm{~kg}$. Jumlah sisa sampah yang ditimbang telah dicatat pada borang soal selidik. Untuk tujuan kajian komposisi, respoden dikehendaki menyimpan hasil buangan selama sehari (24 jam) untuk tujuan tersebut. Lawatan pertama dijalankan untuk memastikan responden memahami prosedur kajian ini. Lawatan kedua dilakukan pada keesokan hari untuk proses menimbang dan pengasingan sisa.

Kajian ini dilakukan di daerah Tawau yang merupakan bandar ketiga terbesar di Sabah yang terletak kira-kira $500 \mathrm{~km}$ dari Kota Kinabalu. Tawau meliputi kawasan seluas $6125 \mathrm{~km}$ persegi atau 612,506 hektar dan bersempadan dengan Kalimantan, Indonesia di selatan dengan kedudukan di garisan bujur 117' ke timur dan 4'30' di garisan lintang ke utara (Majlis Perbandaran Tawau, 2017). Sehingga tahun 2010, populasi penduduk di Tawau dianggarkan berjumlah 398,475 orang berbanding dengan tahun 2000 iaitu sebanyak 305,080 orang dengan pertambahan sebanyak 93,395 orang penduduk (Jabatan Statistik dan Perangkaan Malaysia, 2010). Seterusnya, kawasan kajian yang telah dipilih ialah perumahan Taman Megah Jaya dan Kg. Rawa-Rawa. Kedua-dua kawasan perumahan ini terletak di KM 7 dan Batu 4 Jalan Apas. Pemilihan kedua-dua kawasan iaitu Taman Megah Jaya dan Kg. Rawa-Rawa untuk mengenal pasti perbezaan komposisi sisa pepejal di kawasan tersebut (Rajah 1). 


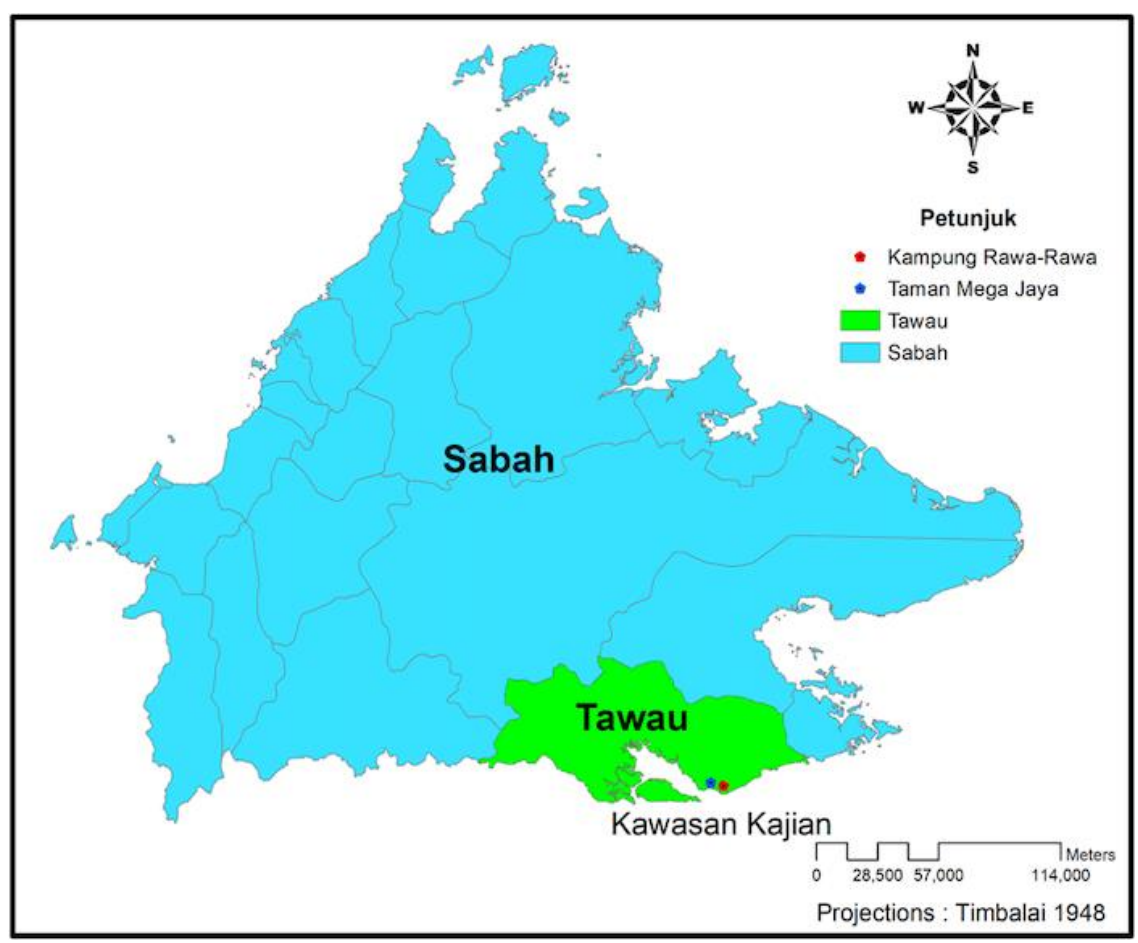

Sumber: Diubahsuai daripada Google Map

Rajah 1. Kawasan kajian

\section{Hasil kajian dan perbincangan}

\section{Demografi responden}

Dari 100 responden yang ditemui, 50 adalah daripada Taman Megah Jaya dan selebihnya dari kawasan perumahan Kg. Rawa-Rawa. Di Taman Megah Jaya, 20.0\% responden adalah lelaki manakala selebihnya iaitu perempuan. Kg. Rawa-Rawa pula terdiri daripada 50 responden, 26 peratus adalah lelaki dan selebihnya adalah perempuan. Secara keseluruhannya, 45.0\% responden daripada perumahan Taman Megah Jaya berketurunan Bugis, 20.0\% adalah Melayu, $10 \%$ adalah dari suku Bajau, $11 \%$ adalah dari suku Suluk, manakala selebihnya adalah responden dari suku Iranun, Jawa, Sungai, Bisaya dan Cina. Pembahagian responden mengikut agama mendapati $85.0 \%$ responden beragama Islam, sembilan peratus Kristian dan enam peratus beragama Budhha. 28.0\% responden yang ditemui mempunyai latar belakang pendidikan bertaraf SPM dan STPM, 16.0\% memiliki ijazah pertama, 56.0\% mempunyai pendidikan PMR/SRP dan ke bawah dengan lebih separuh tidak pernah bersekolah.

\section{Penjanaan dan komposisi sisa}

Analisis komposisi dalam kajian ini dijalankan dengan menggunakan pembahagian komposisi seperti yang digunakan dalam Akta Pengurusan Sisa Pepejal dan Pembersihan Awam 2007 (Akta 672) yang dikuatkuasakan oleh Jabatan Pengurusan Sisa Pepejal dan Pembersihan Awam bagi negeri-negeri di Semenanjung Malaysia. Kajian penjanaan dan analisis komposisi dilakukan keatas semua 100 buah rumah di kedua-dua kawasan perumahan. Pengiraan dan penimbangan 
sisa yang dijalankan adalah berdasarkan berat sisa yang ditimbang semasa kerja lapangan. Hasil kajian mendapati jumlah keseluruhan sisa di 100 buah rumah ialah $661.64 \mathrm{~kg}$. Jumlah ini meliputi $408.69 \mathrm{~kg}$ bagi perumahan kampung Rawa-Rawa dan $252.44 \mathrm{~kg}$ bagi perumahan Taman Megah Jaya. Hasil dapatan ini boleh dijelaskan bahawa kawasan perumahan kampung menghasilkan lebih banyak sisa berbanding kawasan perumahan rumah teres. Kajian lepas menjelaskan jumlah penjanaan adalah berkadar langsung dengan jumlah isi rumah. Dalam kajian ini, jumlah isi rumah bagi perumahan Taman Megah Jaya ialah 6.6 orang dan 8.3 orang bagi perumahan Kg. Rawa-Rawa. Secara purata jumlah sisa yang dihasilkan oleh setiap individu di kawasan kajian ialah $0.89 \mathrm{~kg} / \mathrm{hari} /$ orang. Secara pecahannya, purata sisa bagi setiap individu di kawasan perumahan Taman Megah Jaya ialah 0.76. Manakala, di kawasan perumahan Kg. Rawa-Rawa purata sisa bagi setiap individu ialah $0.98 \mathrm{~kg} / \mathrm{hari} /$ orang. Justeru itu, perbezaan ketara penghasilan sisa di kedua-dua kawasan dalam kajian ini banyak dipengaruhi oleh jumlah isi rumah. Dari analisis tersebut boleh dikatakan, perumahan kampung menghasilkan sisa per individu yang lebih tinggi berbanding kawasan taman perumahan. Kajian komposisi di Malaysia secara umumnya menunjukkan kadar penghasilan sisa perkapita ialah kira-kira 0.5-0.8 kg/orang/hari (Samsudin \& Mat Don, 2013), manakala data Kementerian Perumahan dan Kerajaan Tempatan (2018) menunjukkan purata sisa perkapita sehari di negara ini ialah 0.76 seorang. Secara umumnya, ini dikaitkan dengan budaya dan tabiat penggunaan menyumbang kepada penghasilan dan komposisi sisa pejal domestik (Han et al., 2018).

Kajian ini juga mendapati jumlah sisa yang dijana sedikit sebanyak dipengaruhi oleh faktor kekerapan menjamu di luar rumah. Sisa makanan adalah antara mempunyai kesan ke atas janaan sisa di sesuatu kawasan perumahan. Dapatan kajian ini menunjukan responden di Taman Megah Jaya lebih banyak mengamalkan menjamu di luar rumah berbanding responden di kawasan $\mathrm{Kg}$. Rawa-Rawa. Sebanyak 60.0\% responden di Taman Megah Jaya mengamalkan makan di luar rumah sekurang-kurangnya sekali dalam seminggu. Malah didapati $22.0 \%$ daripada 50 responden yang ditemui di taman perumahan taman tersebut mengamalkan menjamu di luar rumah antara empat hingga tujuh kali dalam seminggu. Dapatan sebaliknya diperhatikan di kawasan perumahan kampung dengan majoriti responden 23 responden (46.0\%) jarang makan diluar dan $22.0 \%$ responden tidak pernah makan di luar. Analisis ini secara kasarnya menunjukkan bahawa kekerapan menjamu atau makan di luar juga memberi kesan yang signifkan kepada jumlah sisa yang dihasilkan.

Berdasarkan Rajah 2, daripada keseluruhan jumlah sisa baki iaitu seberat $339.39 \mathrm{~kg}, 141.72$ $\mathrm{kg}$ atau $42.0 \%$ adalah sisa dapur, $82.97 \mathrm{~kg}$ (24.0\%) adalah bahan kotor, sisa makanan pula adalah sebanyak $62.25 \mathrm{~kg}(18.0 \%)$ manakala lampin pakai buang adalah sebanyak $52.45 \mathrm{~kg}(16.0 \%)$. Terdapat perbezaan penghasilan sisa baki di kedua-dua kawasan perumahan seperti yang ditunjukkan dalam Jadual 1. Seperti yang dijelaskan di atas, kekerapan responden menjamu di luar rumah dilihat memberi kesan secara tidak langsung kepada penghasilan sisa jenis ini. 


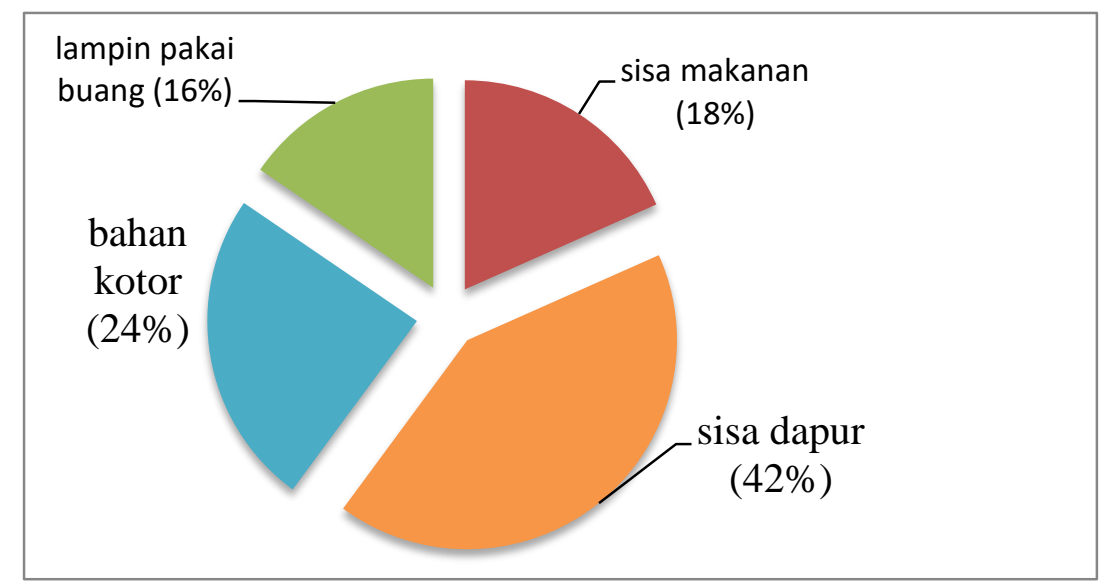

Rajah 2. Jumlah komposisi sisa baki

Jadual 1. Perbezaan sisa baki

\begin{tabular}{lcc} 
Jenis sisa baki & \multicolumn{2}{c}{ Jumlah komposisi sisa (kg) } \\
& Taman Megah Jaya & Kg. Rawa-Rawa \\
\hline Sisa makanan & 27.82 & 34.43 \\
Sisa dapur & 56.93 & 84.79 \\
Bahan-bahan kotor & 33.21 & 49.76 \\
Lampin pakai buang & 23.72 & 28.73 \\
\hline
\end{tabular}

Rajah 3 dan Jadual 2 menunjukkan jumlah bahan sisa kitar semula yang terdapat dalam kajian komposisi sisa di kedua-dua kawasan perumahan. Dapatan menunjukkan sisa kebun adalah komposisi sisa yang paling banyak didapati di kedua-dua kawasan kajian. Jumlah penjanaan didapati berbeza antara kedua-dua kawasan. Hal ini disebabkan oleh faktor persekitaran rumah iaitu kawasan perumahan kampung mempunyai banyak tanaman di kawasan persekitaran rumah dan mempunyai kawasan halaman yang lebih luas untuk melakukan aktiviti penanaman. Berbanding dengan kawasan perumahan taman, sebahagian besar dari rumah di kawasan tersebut tidak mempunyai penjanaan sisa kebun. 


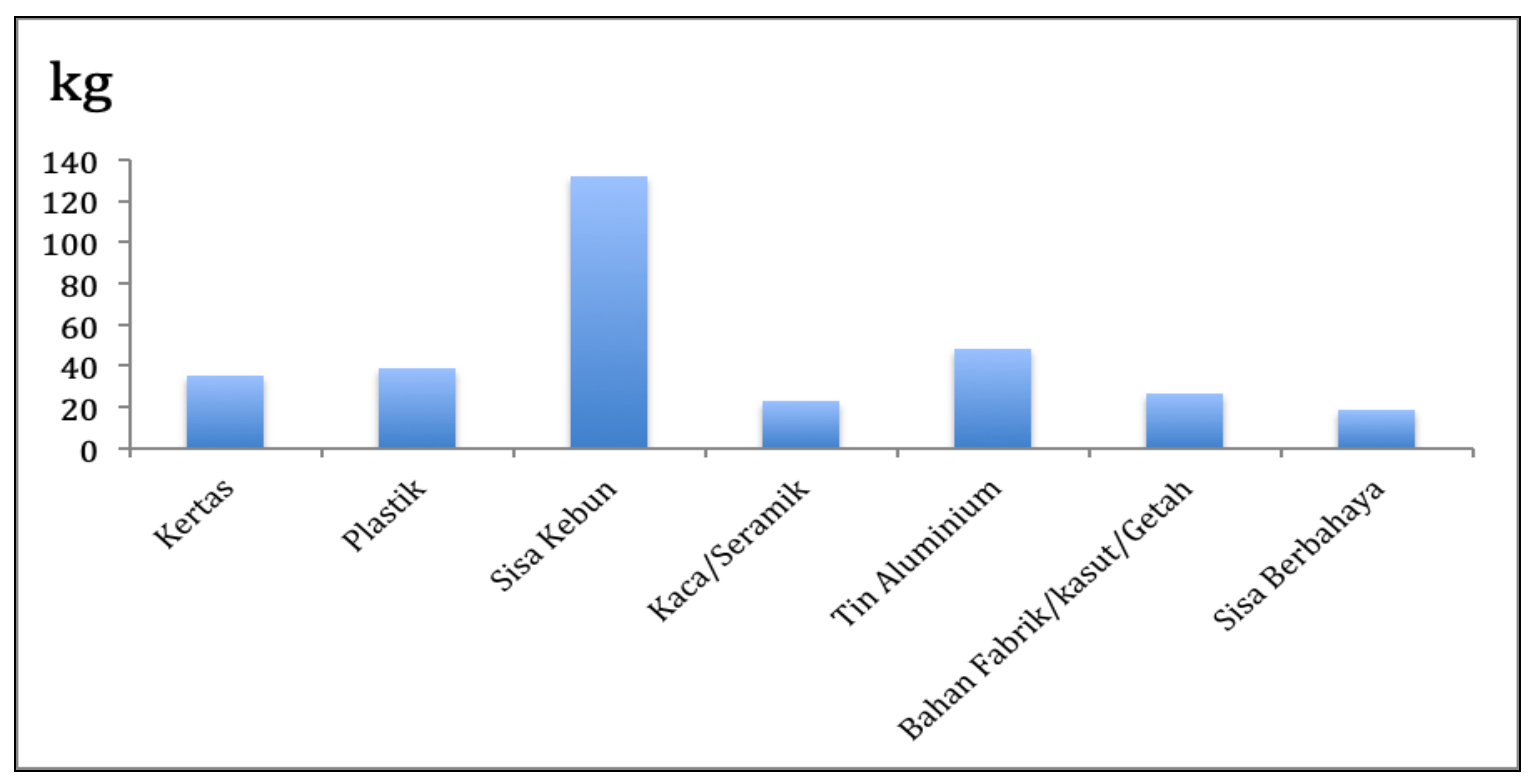

Rajah 3. Jumlah komposisi (kg) sisa kitar semula

Sisa berasaskan logam seperti aluminium dan besi adalah sisa yang kedua paling banyak didapati dalam komposisi sisa (Rajah 3). Sisa-sisa lain yang didapati dalam komposisi adalah seperti sisa plastik pula $(38.55 \mathrm{~kg})$, sisa kertas $(34.99 \mathrm{~kg})$, sisa $\mathrm{kaca} /$ seramik $(23.24 \mathrm{~kg})$, sisa fabrik / kasut / getah (26.32 kg) dan sisa berbahaya $(18.73 \mathrm{~kg})$. Secara umumnya, kajian ini membuktikan bahawa banyak sisa kitar semula boleh diperolehi di kawasan kajian dengan jumlah yang berbeza. Misalnya di kawasan perumahan taman, sisa kertas adalah kedua tertinggi manakala di kawasan perumahan kampung sisa berasaskan logam (tin aluminium) adalah yang kedua paling banyak didapati dalam komposisi sisa selepas sisa kebun (Jadual 2). Kajian komposisi di Malaysia mendapati 70-80 peratus dari sisa yang dibuang ke tapak pelupusan adalah terdiri dari sisa kitar semula (Moh \& Abd Manaf, 2014).

Jadual 2. Kadar jumlah komposisi (kg) sisa kitar semula

\begin{tabular}{lcc}
\hline Jenis Sisa Kitar Semula & Taman Megah Jaya & Kg. Rawa-Rawa \\
\hline Kertas & 23.22 & 11.77 \\
Plastik & 17.4 & 21.15 \\
Sisa kebun & 25.06 & 106.94 \\
Kaca/ seramik & 14.68 & 8.56 \\
Tin aluminium & 12.19 & 35.72 \\
Bahan fabrik/ kasut/ getah & 10.43 & 15.89 \\
Sisa berbahaya & 7.78 & 10.95 \\
\hline Jumlah $(\mathrm{kg})$ & 110.76 & 210.98 \\
\hline
\end{tabular}

\section{Pengasingan sisa}

Perbezaan jumlah dan jenis komposisi sisa yang diperolehi daripada kajian ini dipengaruhi oleh aktiviti pengasingan yang diamalkan oleh responden. Dapatan menunjukkan responden di kawasan perumahan kampung lebih ramai melakukan pengasingan berbanding responden di 
kawasan perumahan taman (Rajah 4). Dapatan ini juga menunjukkan responden mengamalkan pengasingan lebih dari satu jenis sisa. Tin aluminium, besi dan botol plastik adalah bahan sisa kitar semula yang paling banyak diasingkan oleh responden. Jika ini dapat diteruskan, ianya boleh membantu negara mencapai sasaran kitar semula 20.0\% pada tahun 2020 (Moh \& Abd Manaf, 2017). Aktiviti pengumpulan sisa boleh kitar ini boleh dikaitkan dengan faktor permintaan serta harga yang ditawarkan di pasaran pada ketika kajian ini dijalankan. Selain itu, pengasingan sisa juga banyak dipengaruhi oleh faktor lain seperti pentingnya menjaga kebersihan.

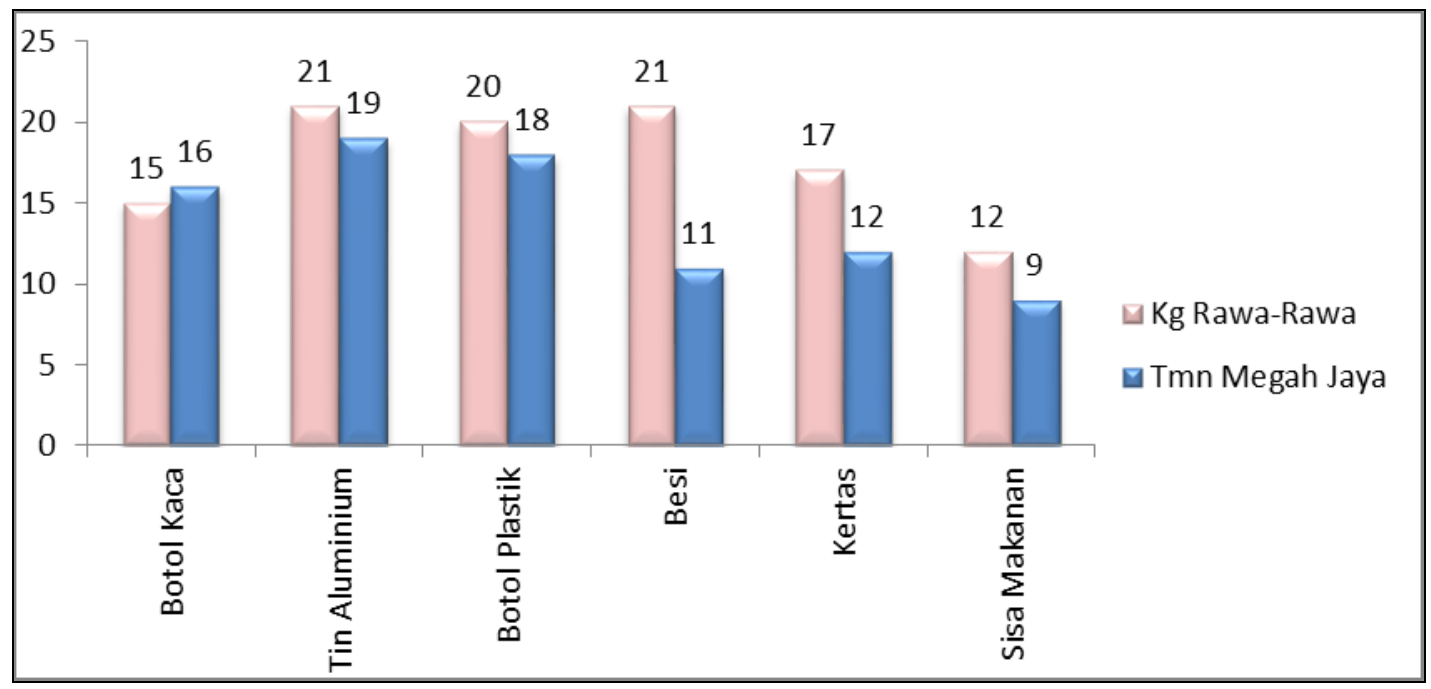

Rajah 4. Bilangan responden yang terlibat dalam pengasingan sisa kitar semula

Jadual 3 menunjukkan bahawa faktor kewangan menjadi antara faktor pendorong pengasingan dilakukan. Kajian di Negeri Sembilan mendapati kira-kira $60.0 \%$ responden menjual barangan kitar semula seperti besi, tin aluminium, kertas, bahan plastik dan botol kaca kepada peniaga atau pengusaha kitar semula (Sakawi et al., 2017). Responden daripada kawasan perumahan kampung didapati lebih terdorong oleh faktor kewangan berbanding perumahan taman. Faktor lain seperti untuk diguna semula dan memenuhi masa lapang juga dinyatakan oleh responden sebagai sebab melakukan pengasingan. Walaupun aktiviti pengasingan banyak dilakukan, namun masih terdapat peratusan yang tinggi (59.0\%) tidak menjalankan pengasingan. Bagi kebanyakan masyarakat yang tidak prihatin kepada keperluan pengasingan sisa, sebahagiannya menggunakan kaedah kumpul dan bakar kerana lebih mudah dipraktikkan (Nurpratiwiningsih et al., 2015). Oleh itu, adalah perlu untuk difikirkan kaedah terbaik untuk mengalakkan penduduk di kedua-dua kawasan melakukan pengasingan untuk tujuan kitar semula. Kajian seperti ini penting dalam menyediakan maklumat dalam menentukan anggaran sisa, membantu mereka bentuk peralatan pemprosesan, penyediaan teknologi yang sesuai untuk merawat sisa (National Solid Waste Management Department, 2013). Sisa perbandaran dari kawasan perumahan adalah tanggungjawab penduduk setempat selain pihak lain seperti PBT. Matlamat utama dari pengurusan sisa ialah untuk menghalang pembuangan sisa atau jika perlu dibuang, mengitar semula adalah pilihan terbaik untuk mengurangkan sisa ke tapak pelupusan (Kumar, 2016). 
Jadual 3. Tujuan pengasingan sisa kitar semula

\begin{tabular}{lcc}
\hline Tujuan Pengasingan & Tmn. Megah Jaya & Kg. Rawa-Rawa \\
\hline Memudahkan pengurusan sampah oleh PBT & 2 & 0 \\
Dijual / mendapatkan sumber kewangan & 9 & 12 \\
Guna semula / mengisi masa lapang & 6 & 8 \\
Menjaga kebersihan & 2 & 2 \\
Tidak melakukan pengasingan & 31 & 28 \\
\hline
\end{tabular}

\section{Kesimpulan}

Secara umumnya, di kawasan kajian beberapa perkara dapat disimpulkan iaitu penghasilan sisa bagi jenis perumahan yang berbeza adalah tidak sama. Perbezaan ketara adalah dari segi jumlah dan komposisi yang dihasilkan. Penduduk di kawasan perumahan kampung didapati menghasilkan sisa lebih banyak sama ada sisa baki atau pun sisa kitar semula. Selain itu, kajian ini mendapati penduduk di kawasan perumahan kampung juga lebih bermotivasi untuk melakukan pengasingan, berbanding mereka di kawasan perumahan taman. Faktor kewangan menjadi pendorong utama kepada responden di kawasan perumahan kampung untuk melakukan pengasingan. Kajian komposisi penting untuk diketengahkan kerana dapat memberikan maklumat kepada pihak berkuasa dalam menentukan kaedah terbaik dalam mengurus sisa pepejal di kawasan perumahan. Selain itu, kajian seperti ini juga dapat memberikan panduan mengenai pengurusan yang boleh dirancang terutamanya dengan peningkatan jumlah penduduk yang semakin tinggi pada masa depan.

\section{Rujukan}

Agamuthu, P., Hamid, F.S., \& Khidzir, K. (2009). Evolution of solid waste management in Malaysia: Impacts and implications of the solid waste bill, 2007. Journal of Material Cycles and Waste Management, 11(2), 96-103. http://dx.doi.org/10.1007/s10163-008-0231-3

Alias, F.S., Manaf, L.A., Ho, M., Onn, N., \& Abdullah, S.J.H. (2014). Knowledge and attitude of water villagers' towards solid waste management. British Journal of Arts and Social Sciences, 16(2), 88-100.

Fatikhah, N.D., Ali, H., \& Ahmad, S. (2010). Analisis pengurusan sisa pepejal di pemukiman berpendapatan tinggi dan rendah: Kajian kes di Kepala Gading dan Wakaras, Jakarta Indonesia. Prosiding Persidangan Kebangsaan Ekonomi Malaysia Ke V 2010. Bangi, Fakulti Ekonomi dan Pengurusan Universiti Kebangsan.

Han, Z., Liu, Y., Zhong, M., Shi, G., Li, Q., Zeng, D., \& Xie, Y. (2018). Influencing factors of domestic waste characteristics in rural areas of developing countries. Waste Management, 72, 45-54. http://dx.doi.org/10.1016/j.wasman.2017.11.039

Jabatan Pengurusan Sisa Pepejal Negara . (2018). Pengasingan Sisa Pepejal Di Punca. Retrieved December 7, 2018, from http://jpspn.kpkt.gov.my

Jabatan Pengurusan Sisa Pepejal Negara. (2012). Lab pengurusan sisa pepejal 26 Mac-13 April 2012. Retrieved from http://jpspn.kpkt.gov.my.

Kassim, J. (2006). Kajian penjanaan dan komposisi sisa pepejal di kawasan luar bandar: Kajian kes Kampung Perpat Darat, Rengit, Batu Pahat, Johor. Universiti Teknologi Mara.

Kementerian Perumahan dan Kerajaan Tempatan (KPKT). (2017). JPSPN Statistik bilangan 
insinerator, tapak pelupusan sisa pepejal yang beroperasi dan yang ditamatkan operasi mengikut negeri tahun 2015. Retrieved from http://www.data.gov.my.

Kementerian Perumahan dan Kerajaan Tempatan (KPKT). (2018). Anggaran penjanaan sisa pepejal di Malaysia pada tahun 2012-2017. Retrieved from http://www.data.gov.my.

Kumar, S. (2016). Municipal solid waste management in developing countries: Municipal solid waste management in developing countries. Retrieved from: http://dx.doi.org/10.1201/9781315369457

Majlis Perbandaran Tawau. (2017). Geografi Tawau. Retrieved November 3, 2018, from http://www.mpt.sabah.gov.my/pages/geografi.html

Mapa, M.T., Asmad, M., \& Beddu Asis, A.H. (2015). Sumbangan pekerja tidak formal di tapak pelupusan sampah terhadap kitar semula: Kajian kes tapak pelupusan Bukit Gemuk, Tawau, Sabah. In Ramli, Z., Razman, M.R., Efizon, D., Zakaria, S.Z.S., Arifin, K., \& Ali, M.S.M. (Eds.), Prosiding Seminar Antarabangsa Ke 8 Ekologi, Habitat Manusia dan Perubahan Persekitaran (pp. 127-138). Langkawi, Institut Alam dan Tamadun Melayu (ATMA), Universiti Kebangsaan Malaysia.

Moh, Y., \& Abd Manaf, L. (2017). Solid waste management transformation and future challenges of source separation and recycling practice in Malaysia. Resources, Conservation and Recycling, 116, 1-14. http://dx.doi.org/10.1016/j.resconrec.2016.09.012

Moh, Y. C., \& Abd Manaf, L. (2014). Overview of household solid waste recycling policy status and challenges in Malaysia. Resources, Conservation and Recycling, 82, 50-61. http://dx.doi.org/10.1016/j.resconrec.2013.11.004

National Solid Waste Management Department. (2013). Survey on solid waste composition, characteristics \& existing practice of solid waste recycling in Malaysia. Kuala Lumpur, Jabatan Pengurusan Sisa Pepejal Negara.

Nurpratiwiningsih, L., Suhandini, P., \& Banowati, E. (2015). Pengelolaan sampah rumah tangga berbasis masyarakat di kelurahan Sekaran Kecamatan Gunungpati Kota Semarang. Journal of Educational Social Studies, 4(1), 1-6. http://dx.doi.org/10.15294/jess.v4i1.6862

Sakawi, Z., Ayup, S., \& Sukimi, M.F. (2017). Pengetahuan komuniti dan amalan pengurusan sisa pepejal di Negeri Sembilan. Geografia: Journal of Society and Space, 13(4), 126-137.

Samsudin, M.D.M., \& Mat Don, M. (2013). Municipal solid waste management in Malaysia: Current practices, challenges and prospects. Jurnal Teknologi, 62(1), 95-101. http://dx.doi.org/10.11113/jt.v62.1293

SUDP (2000). Integrated solid waste management strategy. Sustainable Urban Development Project - Sabah. Kota Kinabalu, Kota Kinabalu City Hall.

Ta Wee, S. (2004). Pengurusan sisa pepejal di Malaysia. Jurnal Sains Sosial, 2(1), 9-25.

UNEP. (2001). Integrated solid waste management. In McDougall, F.R., White, P.R., Franke, M., \& Hindle, P. (Eds.), Journal of Environmental Health. Oxford, UK, Blackwell Publishing Company. http://dx.doi.org/10.1002/9780470999677 